Revista de Medicina

nomactos sasmana on

Prof. RUbiāo MEIRA

Orgam do CENTRO academico

REDACTOR-CHEFE

ANTONIO DA PALMA

\title{
O EXEMPLO DE PASTEUR
}

$\mathrm{Ha}$ apenas cerca de dois mezes que na França, com grande e significativo enthusiasmo, prestaram-se á memoria do maior vulto da Medicina dos tempos modernos, Luiz Pasteur, homenagens excepconaes.

Desejámos seguir em espirito - e o fisémos - os actos que lá se praticaram...

Mas não só nisso havemos de ficar.

Queremos ainda recordar o nome de Pasteur de um modo mais expressivo: e para dizer alguma cousa sobre a vida e as obras deste homem que tão bem encarnou e tão alto levou a representação do typo de sabio-christão, ıdamos, noutra parte, a traducção livre de um estudo feito sobre a sua personalidade por um medico francez, membro da Academia de Medicina de Paris, para uma revista scientifica parisiense.

No nosso numiero de maio noticiámos ligeiramente o que se deveria fazer na França, sua patria, em homenagem ao portentoso trabatho do seu genio.

Effectivamente, nos ultimos dias da segunda quinzena de maio houve na Sorbonne a sessão solenne commemorativa, além doutros actos, e nella falou, em nome dos delegados sul-americanos, o chefe da representação brasileira, o eminente dr. Carlos Chagas. Alguns dias depois, em junho, inauguraram-se em Estrasburgo a exposição de Hygiene e o monumento.

Em todo o mundo, onde quér qué tenha surgido, peì.a applicação de principios firmados ne sua verdade scientifica pela sabedoria do - grande filho de Dôle, algum bem-estar para a humanidade, tem havido tambem, cem anno's pas'sados sobre o seu nascimento allguma homenagem, inda que simples - não importa - á sua memoria, algo. santa.

Pois tambem nós, que tão intimamente nos ligamas ao ramo do saber humano que Pasteur tanto ennobreceu e elevou, entendemos que não devemos silenciar o nosso sentimento. 
Ao lembrar, porém, o seu nome os seus traballhos, e ao contemplar a gloria que hoje brota, irradia e envolve os lugares por onde passou, por onde viveu Pasteur, permittam-nos os moços da Faculdade, principalmente aquelles para os quaes algumas ideações formałm a figura harmoniasa que a imaginação se compraz em considerar a visão archetypuica da sua vida inteira - daqui até a monte - dizermos-lihes que, afinal, a vida de Pasteur foi isso tambem - guardadas certas proporções de tempo e de lugar; de meio e de momento historico, naturalmente: a previsão, nitida d'um destino que devia realisar-se; o esforço herculeo que, cada dia, realisou uma parcella delle; afinal, a glorificação. Esta só hoje surge, e nóṣ"a contiempllamos emoreionados.

Mas andou num embervecimento tão vivo, tão palpitante, tão "actual" das razões de ser da sua vida, o grande sabio, que os seus trabalhos, os seu's descobrimentos vieram, uns após outros, na ordem natural, expontanea, de effeitos. d'uma mesima causa que alctou continuamente sobre 0 mundo material, vencendo-o e revelando-o á sciencia e á industria dos homens - ao seu bem temporal portanto.

E ainda amou bastante a sua patria para mostrar ao governo o criminoso descaso en que deixava os institutos de ensino superior do paiz - triste verdade cruelmente confirmada na humilhação de Sédan.

Evidentemente, na vida do mundo, a vida de calda um de nós, na họra quie vae passando, aqui onde estamos, não converge injunçốs de circumstancias favoraveis ao apparecimento, por estas plagas, da1gum novo Pastieur...

Seria até risivel pensar nisto.

Mas - e isto não tem nada de risivel - o segredo de todas as realizaçōes, da's mais humildes ás mais fulgurantes e grandiosas, é a serena confiança em si. meșmo e a continuidade no trabalho...

Não se proponha um homem absurdos, e certamente realisará o que se houver proposto, isi, nas fataes momentos de idesalento, repousar os olhos em exemplos como o deste genio da latinidade.

Dentro Idas adversidades que continuamente o hostilisaram, Pasteur é uma lindis'sima affirmação do que póde uma'vontade que sabe querer...

Gloria a elle, pois, que tanto e tão bem trabalhou na causa da ventura terrena de toda a humanidade!

Gloria ao.homem genial que soube, na vida, ào serviço do Bem, traçar existencia, na sua immenșa proficiencia, tão rutilante e tão püra! 